ARTICLE

Received 17 Jul 2014 | Accepted 12 Nov 2014 | Published 20 Jan 2015

\title{
From post-BRICS' decade to post-2015: insights from global governance and comparative regionalisms
}

Timothy M Shaw ${ }^{1}$

ABSTRACT 2015 is a symbolic turning point for "development" as eight UN MDGs are superseded by even more SDGs with a focus on global partnerships. This paper exploits the "post-2015" mantra to ask whether the rise of the BRICS and myriad non-state actors/ coalitions, let alone the difficulties of the PIIGS in the Eurozone, suggests that "development" has become passé: Does the rise of "emerging" economies/powers in the current decade mean that we need another paradigm, such as "global governance" along with "new regionalisms"? This overview seeks to identify some of the parameters of international relations/organization/law/political economy for the embryonic Palgrave Communications network for its first 5 years, informed by our new US PhD in Global Governance \& Human Security at UMass Boston. 


\section{Introduction}

...the day-to-day transnational dealings among individuals, firms \& non-governmental organizations (NGOs) dwarf intergovernmental relations by many orders of magnitude. In building on earlier ... work ... this program ... responds to long-standing calls for greater attention to nonstate entities in IR. (Findley et al., 2013: 660)

\section{T} he FIFA World Cup was not the only historic global event in Brazil in mid-2014: it also hosted the BRICS sixth summit in Fortalesa, that is, the start of the BRICS' second half-decade. This led to the establishment to the BRICS Bank. This, and other changes in and around the BRICS, will have some impact on who wins at the next Olympics in mid-2016 in Rio then Tokyo (2020) and next World Cup in Qatar (2022).

This essay looks at the BRICS's decade, the first of this century, and debates about what follows the Millennium Development Goals (MDGs) after 2015. It seeks to situate the rise of the "global South" and its implications for global development/security through the analytic frameworks of global governance and comparative regionalisms. As the 2013 Human Development Report from the UNDP asserts with implications for both policy and theory:

The South has risen at an unprecedented speed \& scale ... By 2050, Brazil, China \& India combined are projected to account for $40 \%$ of world output in purchasing power parity terms ...

The changing global political economy is creating unprecedented challenges and opportunities for continued progress in human development. (UNDP, 2013: 1, 2)

But, the post-2015 era is likely to be different from that anticipated by the UN post-MDGs (http://www.post2015hlp.org): as the global South comes to overshadow the hitherto hegemonic North (Abdenaur and Fonseca, 2013) (http://www.post2015.org, http:// www.beyond2015.org), so its own regionalisms may come to balance, even challenge, the EU as "model" (Fanta et al., 2013; Vivares, 2014). And the end of 2015 is the twenty-first UNFCCC COP in Paris, the last chance for a post-Kyoto environment agreement?

Such novel regional directions are reinforced by burgeoning MNCs, including state-owned enterprises (SOEs), especially national oil companies (NOCs), based in the South (Nolke, 2014). Emerging Markets (EMs) are increasingly familiar in the global economy; now mid-decade the new BRICS of 2015 are the Frontier Markets (FMs) of the second world reflected in CIVETS and VISTA. So comparative regionalisms are impacted by the presence/role of EMs and FMs, concentrated in Africa, South America and Central Europe; FM Exchange-Traded Funds (ETFs) tend to focus on Chile, Poland, Argentina, Columbia, Egypt and so on. Mahrenbach (2013) first juxtaposed EP and EM; that is, emerging powers/markets, paralleling Pieterse (2011) on what is emerging: societies, companies, states and so on?

What are the implications for the practice and analysis of comparative development/international or comparative political economy/ regionalisms? Together such compatible, exponential changes point towards a new international political economy (IPE) in both theory and policy: reorder/or disorder? This paper is informed by animating a new PhD at UMass Boston on Global Governance \& Human Security and continuing after three decades to edit the IPE Series for Palgrave Macmillan with its focus on the global South.

I juxtapose global governance and comparative regionalisms as approaches which have been advanced in both theory and policy by the global crisis and related restructuring. I build on the increasingly familiar and compatible concepts of the "transnational" (Hale and Held, 2011) and "global governance"
(Harman and Williams, 2013; Weiss and Wilkinson, 2014a, b), as together they advance analysis of new regionalisms, especially around natural resources (NRs) in Africa as elsewhere, symbolized by the Kimberley Process (KP) and Extractive Industries Transparency Initiative (EITI). As Weiss and Wilkinson (2014b) rhetorically suggest, the generic, inclusive "global governance" approach may yet "save" established genres like international relations/law/organization (IR/IL/IO), even IPE, as they no longer treat "real"-world issues?

Arguably, then, the first decade of the twenty-first century was that of the BRICs/BRICS, especially China and India, leading Pieterse (2011: 22) to assert that the established N-S axis is being superseded by an E-S one:

... the rise of emerging societies is a major turn in globalization ... North-South relations have been dominant for200 years and now an East-South turn is taking shape. The 2008 economic crisis is part of a global rebalancing process.

Such reordering if not disordering, given the intrusion of EMs and FMs, will impact the practice and analysis of IPE post-2015 (Overbeek and van Apeldoorn, 2011), especially in the democratic capitalist BRICS economies of Brazil and India (Mahrenbach, 2013).

\section{The post-2015 global political economy}

To situate post-2015, this paper juxtaposes a set of parallel/ overlapping perspectives to consider whether the several "worlds"from North Atlantic/Pacific and onto Eurozone PIIGS versus "second world" (Khanna, 2009) of BRICS/CIVETS/MINT/MIST/ VISTA-have grown together or apart as global crises and reordering have proceeded (see myriad heterogeneous analyses such as Cooper and Antkiewicz, 2008; Cooper and Flemes, 2013; Cooper and Subacchi, 2010; Economist, 2012; Gray and Murphy, 2013; Lee et al., 2012; Pieterse, 2011; US National Intelligence Council (USNIC), 2012; WEF, 2012; World Bank, 2012; O’Neill, 2011). Such acronyms reflect methodology/hierarchy: so, CIVETS includes more EMs if not EPs than the rest even more than VISTA as it starts with Columbia.

In turn, "contemporary" "global" issues-wide varieties of ecology, gender, governance, health, norms, technology and so on (see "Emerging 'global' issues") — have confronted established analytic assumptions/traditions and actors/policies (Weiss and Wilkinson, 2014a) leading to myriad "transnational" coalitions and heterogeneous initiatives/processes/regulation schemes as overviewed in Bernstein and Cashore (2008), Dingwerth (2008), Hale and Held (2011) (see "Varieties of transnational governance"); these impact prospects for sustainable regional development in Africa as elsewhere. And Richey and Ponte (2014) suggest that "development" is increasingly "alliances" or networks, including "new" actors. Such extra- or semistate hybrid "global governance" increasingly challenges and supersedes exclusively interstate international organization/law (Harman and Williams, 2013; Weiss and Wilkinson, 2014a, b).

Each set of EMs and now FMs embody slightly different sets of assumptions/directions/implications; PWC expanded the "Next-11" of both EMs and FMs of Goldman Sachs (that is, 15 without RSA) to 17 significant EMs/FMs by 2050 (Hawkesworth and Cookson, 2008). Symptomatically, the initial iconic acronym was proposed at the start of the new century by a leading economist working for a global financial corporation-O'Neill (2011) of Goldman Sachs (http://www2.goldmansachs.com)who marked and reinforced his initial coup with celebration of its first decade. As he notes, global restructuring has been accelerated by the simultaneous decline not only of the United States and the 
United Kingdom but also the southern members of the eurozone. Many now predict China to become the largest economy by 2025 and India to catch-up with the United States by 2050 (Hawkesworth and Cookson, 2008: 3). PWC $(2013: 6,8)$ suggests that:

The E7 countries could overtake the G7 as early as 2017 in PPP terms ... the E7 countries could potentially be around $75 \%$ larger than the G7 countries by the end of 2050 in PPP terms...

By 2050, China, the US and India are likely to be the three largest economies in the world...

But Brown (2013: 168-170) notes that there are competing prophecies about the cross-over date when China trumps the United States, starting with the IMF advancing it to 2016.

As the G8 morphed into G20 (Cooper and Antkiewicz, 2008; Cooper and Subacchi, 2010), a variety of analysts attempted to map the emerging world, including Khanna's (2009) “second world" and Zakaria's (2011) "rest", for example:

(a) The WEF's Global Redesign Initiative (GRI) which included a small state caucus centred on Qatar, Singapore and Switzerland (Cooper and Momani, 2011) (for a readers' guide to GRI, see http://www.umb.edu/cgs/research/global_redesign_initiative).

(b) The Constructive Powers Initiative advanced by Mexico (http://www.consejomexicano.org/en/constructive-powers) which brought older and newer middle powers together (Jordaan, 2003) such as the old Anglophone Commonwealth with inter alia Indonesia, Japan and South Korea.

(c) At the end of 2012, from both sides of the pond, the USNIC produced "Global Trends 2030: Alternative Worlds" (GT 2030) (http://www.gt2030.com) which identified four "megatrends" like "diffusion of power" and "food, water, energy nexus"; a half-dozen "game-changers"; and four "potential worlds" from more to less conflict/inequality, including the possibilities of either China-US collaboration or of a "nonstate world"; and KPMG (2014: 3) produced its own "Future State 2030" with parallel megatrends including "economic power shift" and "resources stress" especially around "essential NRs": "water, food, arable land \& energy".

(d) Chatham House in London reported on "Resources Futures" (Lee et al., 2012: 2) with a focus on "the new political economy of resources" and the possibility of natural resource governance (NRG) by the "Resource 30" (R30) of major producers/consumers, importers/exporters (http://www. chathamhouse.org/resourcesfutures): G20 including the BRICs, but not BRICS (that is, no RSA), plus Chile, Iran, Malaysia, the Netherlands, Nigeria, Norway, Singapore, Switzerland, Thailand, UAE and Venezuela.

And in the case of the most marginal continent, Africa, its possible renaissance was anticipated at the turn of the decade by the Boston Consulting Group (BCG), the Center for Global Development, McKinsey et al. (Shaw, 2012a), with the Economist admitting in January 2011 that it might have to treat Africa as the "hopeful" rather than "hopeless" continent; as the continent with the most FMs, Africa has been the most resistant to economic contraction from the North. Meanwhile, the supply of development resources including official development assistance (ODA) is also moving away from the old North towards the BRICS (Chin and Quadir, 2012) and other new official EM/EP donors like South Korea and Turkey (Sumner and Kirk, 2014; Sumner and Mallett, 2014) plus private foundations like Gates, faith-based organizations (FBOs), remittances from diasporas, heterogeneous Sovereign Wealth Funds (SWFs) and myriad ETFs and novel sources of finance such as taxes on carbon, climate change, emissions, financial transactions and so on (Besada and Kindornay, 2013; Richey and Ponte, 2014).

\section{Emerging economies/markets/powers/states/societies?}

The salience of EPs/EMs (Mahrenbach, 2013), especially the BRICS and other political economies in the second world, has led to debates about the similarities and differences among emerging economies/markets/middle classes/multinational companies/ states/societies and so on, informed by different disciplinary cannons; for example, by contrast to Goldstein on EMNCs or Mahrenbach (2013) on EPs/EMs, Pieterse (2011) privileges sociologically informed "emerging societies". In turn, especially in IR, there are burgeoning analyses of emerging powers/regional and otherwise (Flemes, 2010; Jordaan, 2003; Nel and Nolte, 2010; Nel et al., 2012), some of which might inform new regionalist perspectives, especially as these are increasingly impacted by the divergence between BRICS and PIIGS of the eurozone. In turn, they inform and advance alternative definitions of and directions for development.

Despite the US subprime and EU euro crises at the start of the twenty-first century, foreign direct investment (FDI) in Africa continues to grow, reaching US $\$ 50$ billion in 2013, primarily from China, India and Malaysia; that is, EMs as well as FMs, even if Taylor (2014) is somewhat sceptical about the continent's sustainable development. With new energy discoveries and investments, a second tier of oil producers has emerged after Nigeria and Angola: Equatorial Guinea, Congo-Brazzaville, Gabon, South Sudan and now Ghana, with Uganda eager to join. Liquefied natural gas is now exported from Nigeria, Equatorial Guinea and Mozambique; will the latter be able to challenge the dominance of Qatar and Australia by 2020? And by late-2014, the World Bank plans to launch a $\$ 1$ billion fund to map the continent's mineral resources to advance the continent's own Africa Mining Vision (AMV) (http://www.africaminingvision.org).

\section{Varieties of development}

"Development" was a notion initially related to postwar decolonization and bipolarity. It was popularized in the "Third World" in the 1960s, often in relation to "state socialism", one party even one man rule, but superseded by neo-liberalism and the Washington Consensus. Yet the newly industrialized countries (NICs) then BRICs and now EMs have pointed to another way by contrast to those in decline like fragile states (Brock et al., 2012); such "developmentalism" (Kyung-Sup et al., 2012) has now even reached Africa (UNECA, 2011, 2012) with its burgeoning FMs as well as EMs. But, while the "global" middle class grows in the South, so do inequalities along with non-communicable diseases (NCDs) like cancer, coronary and diabetes.

Given the elusiveness as well as limitations of the MDGs (Wilkinson and Hulme, 2012), the UN has been debating and anticipating post-2015 development desiderata (http://www.un. org/millenniumgoals/beyond2015) including appropriate, innovative forms of governance as encouraged by networks around INGOs (http://www.beyond2015.org) and think tanks (http:// www.post2015.org) (see "Varieties of transnational governance"). Aid is now about cooperation rather than money per se"alliances" as conceived by Ritchey and Ponte (2014) - as a range of flows, especially from "new" actors, is attracted to as well as from the global South including private capital, FDI, ETFs, philanthropy/FBOs, remittances and SWFs, let alone money-laundering (Shaxson, 2012); ODA by members of the Development Assistance Committee of the OECD (http:// www.oecd.org/dac) is a shrinking proportion of transnational transfers (Brown, 2011, 2013: 24-28; Sumner and Kirk, 2014). Meanwhile, within such dramatic global reordering, the varieties of capitalisms, state and non-state, proliferate. 


\section{Varieties of capitalisms}

As indicated by my focus, the world of capitalism has never been more diverse: from old trans-Atlantic and -Pacific to new-the global South with its own diversities such as Brazilian, Chinese, Indian and South African "varieties of capitalisms" (Nolke, 2014); that is, FMs as well as EPs/EMs (Mahrenbach, 2013)? Goldstein (2007) introduced EM MNCs in the IPE Series I continue to edit for Palgrave Macmillan, including a distinctive second index: five pages of company names of EMNCs (see next paragraph). And in the postneo-liberal era, SOEs, especially NOCs (Xu, 2012), are burgeoning. Both US/UK neo-liberal, continental/Scandinavian corporatist and Japanese/East Asian developmentalist "paradigms" are having to rethink and reflect changing stateeconomy/society relations beyond ubiquitous "partnerships" (Overbeek and van Apeldoorn, 2011). Furthermore, if we go beyond the formal and legal, then myriad informal sectors and transnational organized crime (TOC)/money-laundering are ubiquitous (see "Informal and illegal economies: from fragile to developmental states?").

For the first time, in the "Global Fortune 500" of (July) 2012, MNC HQs were more numerous in Asia than in either Europe or North America. There were 73 Chinese MNCs so ranked (up from 11 a decade ago in 2002) along with 13 in South Korea and 8 each in Brazil and India. Each of the BRICS/EMs/EPs hosted some global brands: for example, Geely, Huawei and Lenovo (China), Hyundai, Kia and Samsung (Korea); Embraer and Vale (Brazil); Infosys, Reliance and Tata (India); Anglo American, De Beers and SABMiller (RSA) and so on.

The pair of dominant economies in Sub-Saharan Africa (SSA) is unquestionably Nigeria and South Africa yet, despite being increasingly connected, they display strikingly different forms of "African" capitalisms and NRG. Nigeria, including its mega-cities like Lagos and Ibadan, is a highly informal political economy with a small formal sector (beer, consumer goods such as soft drinks and soaps, finance, telecommunications and so on); by contrast, despite its ubiquitous shanty-towns, South Africa is based on a well-established formal economy centred on mining, manufacturing, farming, finance, services and so on. Both have significant diasporas in the global North, especially the United Kingdom and the United States, including Nigeria's in RSA, especially Jo' burg, remitting funds back home. Since majority democratic rule, South African companies and supply-chains, brands and franchises have penetrated the continent; initially into Eastern from Southern Africa, but now increasingly into West Africa and Angola.

As reflected in the multiplication of acronyms-MIST/MIST and so on-the post-BRICS era is marked by a proliferation of EMs and now FMs as growth and profits from the BRICS and EMs/EPs decline: onto and beyond the N-11. So the Guggenhiem FMs ETF includes over 40 countries concentrated in the Baltics, the Gulf and ME, Central Europe and South America, some without stock exchanges (http://www.guggenheiminvestments. com). As smaller, less-developed markets, investments risks are higher in FMs than in the BRICS or EMs. And many FM investments are in stocks which grow with the middle classes: BBC of banks, brewers and cement; for example, in Nigeria, Zenith Bank, Nigerian Breweries and Dangote Cement.

Market Vectors ETFs from Van Eck Global include Africa, Brazil, China, Columbia, Egypt, Gulf States, India, Indonesia, Latin America and Vietnam (http://www.vaneck.com); and iShares by BlackRock offers ETFs on Brazil, Chile, Colombia, Mexico, South Africa and Turkey (http://www.iShares.com). Likewise, the top five holdings in Claymore/BNY Mellon FM are: Chile, Poland, Egypt Columbia and Kazakhstan; with holdings concentrated in finance, minerals, utilities, energy and telecoms (http://www.guggenheiminvestments.com). Africa is the classic FM region, increasingly attractive because of its resources and resilience in the face of the "global" recession. But regions in the global South can now be compared in terms of numbers/ dynamism of EMs/FMs: from Africa to Central Asia and onto South America, especially Andean states: Bolivia, Ecuador and Peru.

\section{New regionalisms}

The proliferation of states along with capitalisms postbipolarity has led to a parallel proliferation of regions, especially if diversities of non-state, informal even illegal regions are so considered. And the eurozone crisis concentrated in the PIIGS has eroded the salience of the EU as model leading to a recognition of a variety of "new" regionalisms (Flemes, 2010; Shaw et al., 2011).These include instances of "African agency" (Lorenz-Carl and Rempe, 2013) like South African franchises and supply chains reaching to West Africa and the Trilateral FTA among COMESA, EAC and SADC (T-FTA) (Hartzenberg et al., 2012) along with older/newer regional conflicts like the Great Lakes Region plus the regional as well as global dimensions of, say, piracy off the coast of Somalia (ACBF, 2014; Hanson et al., 2014). The third, ACIR in 2014 from the ACBF (2014) focuses on capacity for regional development. And the latest title in the Ashgate Series on the IPE of New Regionalisms is on Converging Regions: Global Perspectives on Asia \& the Middle East (Lenze and Schriwer, 2014).

Blue-ribbon Commissions on Drugs in Latin America and now West Africa (http://www.wacommissionondrugs.org) indicate how far the new South has come in defining its own agenda, direction and pace. The former predated, the latter postdated, the erstwhile Global Commission on Drugs \& Policy (http://www. globalcommissionondrugs.org), just as social forces in the United States get to decriminalize then incrementally commercialize marijuana.

And increasingly ubiquitous airline alliances link regional hubs including in the global South, especially Asia, from Singapore to Panama. In Southeast Asia, Singapore Airlines/Star Alliance is dominant; likewise, South African/Star Alliance in Africa; but in South America, LAN/oneworld is increasingly hegemonic. And in the Gulf, between Europe and Asia, the trio of burgeoning airlines takes different trajectories: Emirates is its own de facto global alliance; Etihad purchases other carriers from Air Berlin to Alitalia; and Qatar is now oneworld.

\section{Emerging "global" issues}

A growing number of global issues is increasingly recognized arising in the global South as well as resulting from excessive consumption/pollution in the North such as NCDs like diabetes. In the immediate future, these issues will include environmental and other consequences of climate change and health viruses/ zoonoses. They will also extend to myriad computer viruses and cybercrime (Kshetri, 2013). Given the new attention to the energy/food/land/water nexus, some suggest that we may be running out of basic commodities like energy (Klare, 2012) and water let alone rare-earth elements. Finally, after recent global and regional crisis, the governance of the global economy is at stake: the financialization syndrome of DBRAs, derivatives, from EMs to FMs, ETFs/ETNs, hedge and pension funds, SWFs and so on (Overbeek and van Apeldoorn, 2011).

\section{Informal and illegal economies: from fragile to developmental states?}

"Shadow banking" via "shell corporations" has become a set of ubiquitous global networks with centres in London and Miami rather than the Cayman or Virgin Islands (Findley et al., 2014) about which the G20 is rather ambivalent despite is anti-moneylaundering norms and agencies (Findley et al., 2013). Developing 
out of the internet, new mobile technologies increasingly facilitate the informal/illegal as well as otherwise, including the dramatic rise of mobile money in SSA-Mpesa-especially Kenya and RSA. The "informal sector" is increasingly recognized in the discipline of anthropology and so on as the "illegal" in the field of IPE (Friman, 2009; Naylor, 2005); these are increasingly informed by telling Small Arms Survey (SAS) annual reports after more than decade with a focus on fragile states (http://www.smallarms survey.org).

Similarly, TOC is increasingly transnational with the proliferation of (young/male) gangs from myriad states (Knight and Keating, 2010: 274-300). In response, the field of IPE needs to develop analyses and prescriptions from the established informed annual SAS and Latin American then Global Commission on Drugs and Drug Policy/Health (http://www.globalcommissionon drugs.org); and now at start new decade onto Ideas Google re the illicit (http://www.google.com/ideas)? As supply chains shifted away from Central America and the Caribbean to West Africa in response to the "war on drugs", as already noted in "New regionalisms", the Kofi Annan Foundation created a preemptive, preventive West African Commission on Drugs (http://www.wacommissionondrugs.org): another definition of regionalism.

\section{Varieties of transnational governance}

Just as "governance" is being redefined/rearticulated (Bevir, 2011), so the "transnational" is being rediscovered/rehabilitated (Dingwerth, 2008; Hale and Held, 2011) following marginalization after its initial articulation at the start of the 1970s by Keohane and Nye (1972): they identified major varieties of transnational relations such as communications, conflict, education, environment, labour, MNCs, religions and so on; and Harman and Williams (2013) have produced a very useful teaching collection of case studies for the present decade. And Brown (2011) updated such perspectives with a more economicscentred framework which included civil society, remittances and so on. Now Weiss and Wilkinson (2014b) rhetorically suggest that such global governance may yet save IR/IL/IO and so on.

In turn, I would add to global governance such contemporary transnational issues such as brands and franchises; conspicuous consumption by emerging middle classes (from Audis/BMWs/ Mercedes to tourism and, alas, drugs to treat the plague of diabetes); world sports, such as FIFA and IOC; global events from World Fairs to Olympics and world soccer; logistics and supplychains (legal and formal and otherwise); mobile digital technologies including mobile money; new film centres such as Bollywood and Nollywood including diasporas, film festivals, tie-ins and so on; new media such as Facebook and Twitter. But such heterogeneous relations/perspectives, including KP, EITI and the AMV, deserve further attention in terms of their contribution to sustainable development in Africa and elsewhere.

\section{Global governance and new regionalisms by mid-century?}

In conclusion I juxtapose a trio of changes which will probably impact global governance and comparative regionalisms in policy and practice in Africa and elsewhere post-2015:

(a) exponential global restructuring in myriad areas, from economics and ecology to diplomacy and security (Besada and Kindornay, 2013; Overbeek and van Apeldoorn, 2011);

(b) shift in the direction and concentration of resource flows and supply chains away from S-N towards S-E; and

(c) continued evolution in multi-stakeholder communities to incorporate SOEs, SWFs, pension funds, ETFs and so on as well as MNCs, especially from the BRICS and other EMs/FMs such as the mid-2014 BRICS Bank, symbolized by UN Global Compact (http://www.unglobalcompact.org) to UN Guiding Principles (http://www.business-humanrights.org); see, for example, http://www.isealalliance.org, http://www.act alliance.org, http://www.eiti.org, http://www.futureearth.org, http://www.onehealthinitiative.com, http://www.stalliance.org and so on.

\section{References}

Abdenur A E and de Fonseca J M E M (2013) The North's growing role in South-South cooperation: Keeping the foothold. Third World Quarterly; 34 (8): 1475-1491.

ACBF (2014) Africa Capacity Report 2014: Capacity Building for Regionalism in Africa. ACBF: Harare.

Bernstein S and Cashore B (2008) The two-level logic of non-state market driven global governance. In: Rittberger V and Nettesheim M (eds) Changing Patterns of Authority in the Global Political Economy. Palgrave Macmillan: London, pp 276-313.

Besada H and Kindornay S (eds) (2013) The Future of Multilateral Development Cooperation in a Changing Global Order. Palgrave Macmillan for NSI: London.

Bevir M (2011) Sage Handbook of Governance. Sage: London.

Brock L, Holm H-H, Sorensen G and Stohl M (2012) Fragile States. Polity: Cambridge.

Brown S (ed) (2011) Transnational Transfers and Global Development. Palgrave Macmillan: London.

Brown S (2013) The Future of US Global Power: Delusions of Decline. Palgrave Macmillan: London.

Chin G and Quadir F (eds) (2012) Rising states, rising donors and the global aid regime. Cambridge Review of International Affairs; 25 (4): 493-649.

Cooper A F and Antkiewicz A (eds) (2008) Emerging Powers in Global Governance: Lessons from the Heiligendamm Process. WLU Press for CIGI: Waterloo.

Cooper A F and Momani B (2011) Qatar and expanded contours of South-South diplomacy. International Spectator; 46 (3): 113-128.

Cooper A F and Flemes D (eds) (2013) Special issue: Emerging powers in global governance. Third World Quarterly; 34 (6): 943-1144.

Cooper A F and Subacchi P (eds) (2010) Overview. International Affairs; 86 (3): 607-757.

Dingwerth K (2008) Private transnational governance and the developing world. International Studies Quarterly; 52 (3): 607-634.

Dunn K C and Shaw T M (eds) (2013) Africa's Challenge to International Relations Theory Revised. Classics publication edition. Palgrave Macmillan: London.

Economist (2012) The World in 2013. London, http://www.economist.com/ theworldin/2013.

Fanta E, Shaw T M and Tang V (eds) (2013) Comparative Regionalism for Development in the Twenty-First Century: Insights from the Global South. Ashgate for NETRIS: Farnham.

Findley M G, Nielson D L and Sharman J C (2013) Using field experiments in IR: A randomized study of anonymous incorporation. International Organization, 67 (4): 657-693.

Findley M G, Nielson D L and Sharman J C (2014) Global Shell Games: Experiments in Transnational Relations, Crime \& Terrorism. Cambridge University Press: Cambridge.

Flemes D (ed) (2010) Regional Leadership in the Global System. Ashgate: Farnham. Friman H R (ed) (2009) Crime and the Global Political Economy IPE Yearbook \#16. LRP: Boulder.

Goldstein A (2007) Multinational Companies from Emerging Economies. Palgrave Macmillan: London.

Gray K and Murphy C (eds) (2013) Special issue: Rising powers and the future of global governance. Third World Quarterly; 32 (2): 183-355.

Hale T and Held D (eds) (2011) Handbook of Transnational Governance. Polity: Cambridge.

Hanson K, D'Alessandro C and Owusu F (2014) Managing Africa's Natural REsources: Capacities for Development. Palgrave: London.

Harman S and Williams D (eds) (2013) Governing the World: Cases in Global Governance. Routledge: Abingdon.

Hartzenberg T et al (2012) The Trilateral Free Trade Area: Towards a New African Integration Paradigm? Tralac: Stellenbosch.

Hawksworth J and Cookson G (2008) The World in 2050: Beyond the BRICs: A Broader Look at Emerging Market Growth. PWC: London.

Jordaan E (2003) The concept of middle power in IR: Distinguishing between emerging and traditional middle powers. Politikon; 30 (2): 165-181.

Keohane R O and Nye J S (eds) (1972) Transnational Relations and World Politics. Harvard University Press: Cambridge.

Khanna P (2009) The Second World: How Emerging Powers are Redefining Global Competition in the Twenty-First Century. Random House: New York.

Klare M T (2012) The Race for What's Left: The Global Scramble for the World's Last Resources. Metropolitan: New York.

Knight W A and Keating T (2010) Global Politics. OUP: Toronto. 
KPMG (2014) Future State 2030: the global megatrends shaping governments, http://www.kpmg.com/government, accessed 8 January 2015.

Kshetri N (2013) Cybercrime and Cybersecurity in the Global South. Palgrave Macmillan: London.

Kyung-Sup C, Fine B and Weiss L (eds) (2012) Developmental Politics in Transition: The Neoliberal Era and Beyond. Palgrave Macmillan: London.

Lee B, Preston F, Kooroshy J, Bailey R and Lahn G (2012) Resources Futures. Chatham House: London.

Lenze N and Schriwer C (eds) (2014) Converging Regions: Global Perspectives on Asia \& the Middle East. Ashgate: Farnham.

Lorenz-Carl U and Rempe M (eds) (2013) Mapping Agency: Comparing Regionalisms in Africa. Ashgate: Farnham.

Mahrenbach L C (2013) The Trade Policy of Emerging Powers: Strategic Choices of Brazil \& India. Palgrave Macmillan: London.

Naylor R T (2005) Wages of Crime: Black Markets, Illegal Finance and the Underworld Economy, 2nd edn. Cornell University Press: Ithaca.

Nel P, Nabers D and Hanif M (eds) (2012) Special issue: Regional powers and global redistribution. Global Society; 26 (3): 279-405.

Nel P and Nolte D (eds) (2010) Regional powers in a changing global order. Review of International Studies; 36 (4): 877-974.

Nolke A (ed) (2014) Multinational Corporations from Emerging Markets: State Capitalism 3.0. Palgrave Macmillan: London.

O'Neill J (2011) The Growth Map: Economic Opportunity in the BRICs and Beyond. Portfolio/Penguin: New York.

Overbeek H and van Apeldoorn B (eds) (2011) Neoliberalism in Crisis. Palgrave Macmillan: London.

Pieterse J N (2011) Global rebalancing: Crisis and the East-South turn. Development and Change; 42 (1): 22-48.

PWC (2013) World in 2050: The BRICs and Beyond: Prospects, Challenges and Opportunities. PWC: London, January.

Ritchey L A and Ponte S (eds) (2014) New actors \& alliances in development. Third World Development; 35 (1): 1-195.

Shaw T M (2012a) Africa's Quest for developmental states: "Renaissance" for whom? Third World Quarterly; 33 (5): 837-851.

Shaw T M, Grant J A and Cornelissen S (eds) (2011) Ashgate Research Companion to Regionalisms. Ashgate: Farnham.

Shaxson N (2012) Treasure Islands: Uncovering the Damage of Offshore Banking and Tax Havens. Palgrave Macmillan: New York.

Sumner A and Mallett R (2014) The Future of Foreign Aid: Development Cooperation and the New Geography of Global Poverty. Palgrave Pivot: London.

Sumner A and Kirk T (eds) (2014) The Donors' Dilemma: Emergence, Convergence and the Future of Foreign Aid. Global Policy: London.

Taylor I (2014) Africa Rising? BRICS-Diversifying Dependence. James Currey: Martlesham, Suffolk.

UNDP (2013) Human Development Report 2013: The Rise of the South: Human Progress in a Diverse World. UNDP: New York.

UNECA (2011) Economic Report on Africa 2011: Governing Development in Africa: The Role of the State in Economic Transformation. UNECA: Addis Ababa.
UNECA (2012) Economic Report on Africa 2012: Unleashing Africa's Potential as a Pole of Global Growth. UNECA: Addis Ababa.

US National Intelligence Council (USNIC) (2012) Global Trends 2030: Alternative Worlds. National Intelligence Council: Washington DC, December, http://www. dni.gov/nic/globaltrends; http://www.gt.com.

Vivares E (ed) (2014) Exploring the New South American Regionalism (NSAR). Ashgate: Farnham.

Weiss T G and Wilkinson R (eds) (2014a) International Organization \& Global Governance. Routledge: Abingdon.

Weiss T G and Wilkinson R (2014b) Global governance to the rescue: Saving international relations? Global Governance; 20 (1): 19-36.

Wilkinson R and Hulme D (eds) (2012) The Millennium Development Goals and Beyond: Global Development after 2015. Routledge: Abingdon.

World Bank (2012) Global Economic Prospects June 2012: Managing Growth in a Volatile World. World Bank: Washington DC.

World Economic Forum (2012) Global Risks 2012: An Initiative of the RRN, 7th edn. World Economic Forum: Davos.

Xu Y-chong (ed) (2012) The Political Economy of State-Owned Enterprises in China and India. Palgrave Macmillan: London.

Zakaria F (2011) The Post-American World: Release 2.0, Updated and expanded edition. Norton: New York.

\section{Acknowledgements}

An earlier, shorter version of this essay originally appeared as the Series Editor's Foreword to the Classics publication reprints published in the Palgrave Macmillan IPE Series in the fall of 2013 (for example, Dunn and Shaw, 2013), usually in pp ix-xxii. To encourage its wider dissemination, this expanded and updated version is being published open access in Palgrave Communications.

\section{Additional information}

Competing interests: The author declares no competing financial interests.

Reprints and permission information is available at http://www.palgrave-journals.com/ pal/authors/rights_and_permissions.html

How to cite this article: Shaw T M (2015) From post-BRICS' decade to post-2015: insights from global governance and comparative regionalisms. Palgrave Communications 1:14004 doi: 10.1057/palcomms.2014.4.

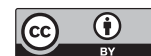

This work is licensed under a Creative Commons Attribution 3.0 International License. The images or other third party material in this article are included in the article's Creative Commons license, unless indicated otherwise in the credit line; if the material is not included under the Creative Commons license, users will need to obtain permission from the license holder to reproduce the material. To view a copy of this license, visit http://creativecommons.org/licenses/by/3.0/ 